\title{
Police Violence and Citizen Crime Reporting in the Black Community
}

\author{
Matthew Desmond \\ Harvard University \\ Andrew V. Papachristos \\ Yale University \\ David S. Kirk \\ University of Oxford
}

Corresponding Author: Matthew Desmond, Department of Sociology, Harvard University, William James Hall, 33 Kirkland Street, Cambridge, MA 02138

E-mail: mdesmond@fas.harvard.edu

\begin{abstract}
High-profile cases of police violence — disproportionately experienced by black men — may present a serious threat to public safety if they lower citizen crime reporting. Using an interrupted time series design, this study analyzes how one of Milwaukee's most publicized cases of police violence against an unarmed black man, the beating of Frank Jude, affected police-related 911 calls. Controlling for crime, prior call patterns, and several neighborhood characteristics, we find that residents of Milwaukee's neighborhoods, especially residents of black neighborhoods, were far less likely to report crime after Jude's beating was broadcast. The effect lasted for over a year and resulted in a total net loss of approximately 22,200 calls for service. Other local and national cases of police violence against unarmed black men also had a significant impact on citizen crime reporting in Milwaukee. Police misconduct can powerfully suppress one of the most basic forms of civic engagement: calling 911 for matters of personal and public safety.
\end{abstract}

\section{Keywords}

crime reporting, police, police violence, race, crime, inner city

High-profile cases of police violence against unarmed citizens can undermine the legitimacy of legal authority. Numerous studies document stark racial disparities in police maltreatment, finding that black boys and men are disproportionately subject to excessive and sometimes deadly police force, even after accounting for situational factors of the encounter (e.g., resisting arrest) and officer characteristics (e.g., age, training) (Terrill and Reisig 2003). Studies show that police disproportionately use improper and deadly force on black men (Matulia 1982; Worden 1996).

With the proliferation of portable video recording technology, police misconduct that was once witnessed only by immediate bystanders can now be viewed around the world; and the rise of Internet-based news sources and 24-hour news networks provide a powerful medium for broadcasting police misconduct. In recent years, the American public has been captivated and outraged by such events. The fatal 2012 shooting of 17-year-old Trayvon Martin by a neighborhood watch coordinator, for example, was the most followed news story in the United States for several straight weeks (Pew Research Center 2012). Other instances of lawenforcement officers killing unarmed black men — such as Eric Garner in New York City (July 2014); Michael Brown in Ferguson, Missouri (August 2014); and Freddie Gray in Baltimore, Maryland (April 2015) — became national news stories and sparked widespread protest. Previous research shows that negative encounters with law enforcement, as well as high-profile cases of police misconduct, contribute to the spread of legal cynicism within black communities (Kirk and Papachristos 2011; Sampson 2012; Weitzer 2002). Less well understood, however, is the extent to which legal cynicism affects citizens' reliance on police. In the aftermath of publicized police violence against unarmed black men, do residents of black neighborhoods 
disengage with the police, especially when it comes to reporting crime via 911? Police work of every kind relies on citizen participation, especially reports of law breaking (Banton 1964; Black 1970). If police misconduct lowers crime reporting throughout black communities, it directly threatens public safety within those communities, many of which already face high levels of crime.

This study examines how incidents of excessive police violence influence citizen crime reporting. As our main case study, we examine one of Milwaukee's most publicized moments of police brutality: the 2004 beating of an unarmed black man, Frank Jude, by white police officers. Using an interrupted time series design, we analyze patterns of police-related 911 calls before and after the Jude beating was made public in the Milwaukee press. Controlling for several neighborhood characteristics, along with fixed effects for neighborhoods and months, we find that residents of Milwaukee's neighborhoods were far less likely to report crime after Jude's beating was broadcast. Over half of the total loss in 911 calls occurred in black neighborhoods. Supplemental analyses of other local and national cases of police violence against unarmed black men also had an impact on crime reporting in Milwaukee.

\section{LEGAL CYNICISM AND CITIZEN CRIME REPORTING}

A spirit of legal cynicism - the deep-seated belief in the incompetence, illegitimacy, and unresponsiveness of the criminal justice system (Kirk and Papachristos 2011) - is thought to pervade many poor, minority communities. Legal cynicism is widely believed to result in citizens withdrawing from the police, particularly by refusing to report crime to the authorities (Baumer 2002). What emerges, in Anderson's (1999:66) classic formulation, is the code of the street, "a kind of people's law" based on respect and payback. Residents who refuse to seek help from the police are thought to rely on the code to dole out sanctions through violence or other informal means (Kirk and Papachristos 2011; Sampson 2012).

The vast majority of research on citizens' views toward the police and law breaking is based on interviews (e.g., Brunson and Miller 2006; Carr, Napolitano, and Keating 2007) or surveys (e.g., Avakame, Fyfe, and McCoy 1999; Baumer 2002). Interviews and surveys can serve as effective methods to capture individuals' attitudes and cultural scripts, but studies show surveys are less reliable when it comes to measuring interactions with the police (Rosenfeld, Jacobs, and Wright 2003). Moreover, a close reading of ethnographic reports reveals that the code's manifestations may not be as uniform as is often believed. At some points, Anderson (1999:72-73, 112) refers to the code as a belief system or cultural frame, but at others he presents it as a dissemblance designed to prevent, not encourage, violence. Cold looks and bold boasts aside, the people Anderson observed often relied on the police, a pattern observed by other urban ethnographers as well (e.g., Sánchez Jankowski 1991; Venkatesh 2000).

When it comes to relying on and cooperating with the police, what one does might not resemble what one says one will do. The legal cynic may report crime just as regularly as the citizen who views the criminal justice system with reverence. Studies that measure attitudes toward the police and hypothesized citizen crime reporting find racial differences in the former but not the latter. Bobo and Thompson (2006) asked respondents (1) if they would call the police and file a report if their house was burglarized and (2) if they believed their complaint would be taken seriously. The vast majority of both white and black respondents (90 and 93 percent,

respectively) said they would call the police; however, only 35 percent of blacks expected to be taken seriously, compared with 60 percent of whites. Although sizeable racial differences were observed in peoples' attitudes toward the police, respondents were virtually identical in their surmised actions with law enforcement. People's attitudes toward the criminal justice system might be poor, even misleading, indicators of their real-life dealings with the police. 


\section{STUDY DESIGN AND RESEARCH QUESTIONS}

This study moves beyond the limitations of previous research by analyzing the effects of publicized police violence cases on crime reporting via 911 calls. The evidence for this study does not rely on accounts of past behavior or projections of future action but on the complete universe of every crime reported in Milwaukee over the course of seven years. Calling 911 to report a crime is the most basic act of reliance on (and engagement with) the legal system in contemporary society (Manning 1988; Reiss 1992). It is also foundational to public safety, being the first and among the most important acts of cooperation with the police, who in many cases can respond to criminal activity only if it is reported.

In studying the effects of highly publicized cases of police misconduct on citizen crime reporting, our study also investigates a possible new mechanism for a reluctance to cooperate with formal law enforcement agencies. Recent studies find that one's attitude toward the police can be influenced by vicarious experiences of one's social ties (Brunson 2007; Rosenbaum et al. 2005) and by repeated exposure to news reports of misconduct (Weitzer and Tuch 2005). Some studies document a drop in public approval of the police after publicized cases of police brutality, especially among African Americans (Jefferis et al. 1997; Weitzer 2002). These studies are primarily descriptive, and they do not control for crime rates. But they do suggest that police violence may have reverberations that extend well beyond the trauma and tragedy of an individual act — or even the neighborhood and city in which it took place.

To examine the relationship between publicized reports of police violence and citizen crime reporting, we examine 911 calls with an interrupted time series design, testing for changes in the volume of 911 calls before and after the Milwaukee Journal Sentinel broke the story of the 2004 beating of an unarmed black man, Frank Jude, by white police officers. We are interested in four aspects of calling patterns. First, we examine the direction of 911 calls reporting crime, observing if they increased, decreased, or experienced no change. Second, we examine patterns in different types of calls: namely through analyses of all calls reporting crime and then separately for calls reporting violence. Third, we focus on the location of calls, observing if calling patterns in white and black neighborhoods differed after the Sentinel reported Jude's assault. Fourth, should there be a "Jude effect" on police-related 911 calls, we investigate its duration. Additionally, we examine if citizen crime reporting in Milwaukee was affected by three other cases of police violence against unarmed black men: the 2007 assault of Danyall Simpson in Milwaukee; the 2006 killing of Sean Bell in Queens, New York; and the 2009 killing of Oscar Grant in Oakland, California. The Simpson case was covered in the local press; the other two cases were major stories in the national press.

In each case we analyze, we assume that breaking the story in mainstream media outlets was what brought the incidents to public light, even if community members did not themselves learn of the incidents through such outlets. Milwaukee residents could have learned of these incidents through public protest, word of mouth, and alternative media, including the black press and underground rap songs, which circulated after the deaths of Oscar Grant and Sean Bell. Nevertheless, news of such incidents spread through various channels only after major media outlets broke the story. This was especially apparent in Frank Jude's case. More than three months elapsed between Jude's beating and it being reported in the local press. During that time, there were no public protests; unrest did follow the news story. Additionally, supplemental analyses find that in black neighborhoods, police-related 911 calls were unaffected in the weeks immediately following Jude's beating. This suggests that although knowledge of an incident of police violence may spread through personal networks close to the victim, those networks are not expansive enough to affect the crime-reporting behavior of an entire community in a compressed timespan (see Andrews and Biggs 2006). Even if they were, media reporting on such episodes draws on medical and police reports, interviews with eyewitnesses, and other 
sources, providing resonance and legitimacy to events that otherwise could be dismissed as hearsay or overlaid with multiple interpretations rooted in assumptions (Koopmans 2004).

\section{THE BEATING OF FRANK JUDE}

What follows is an account of the events surrounding the beating of Frank Jude based on news reports and court documents (listed at the end of the article). To understand how these events could have affected citizen crime reporting in Milwaukee, it is necessary to provide a somewhat detailed account of the severity of Jude's beating and its aftermath.

On October 23, 2004, Milwaukee police officer Andrew Spengler hosted a house warming party in a middle-class white neighborhood. Several police officers attended. After 2:30 a.m., Frank Jude and Lovell Harris, both black men, arrived at the party as guests of two female college students. The group of four began to feel uncomfortable and left the party, returning to the truck in which they had arrived. But before they could pull away, at least 10 men surrounded the truck and accused Jude and Harris of stealing Spengler's police badge. Jude, Harris, and their hosts were pulled from the truck. After having his face slit with a knife, Harris would escape. Jude would not (Diedrich 2005b).

Spengler and several other off-duty police officers began beating Jude about the face and torso while another pinned his arms behind his back. When Jude collapsed to the ground, the officers kicked his head. A pair of on-duty officers arrived around 3:00 a.m. (Jude's female companions had called 911 before partygoers seized their phones.) One uniformed officer, Joseph Schabel, stomped on Jude's face until he heard bones breaking. The other on-duty officer watched. An off-duty officer picked Jude up and kicked him in the crotch with such force his feet left the ground. Another took one of Schabel's pens and pressed it deep into Jude's ear canals. Another bent Jude's fingers back until they snapped. Spengler put a gun to Jude's head. Jude was left naked from the waist down lying on the street in a pool of his own blood. At 3:09 a.m. other onduty officers arrived at the scene. Jude was taken by police wagon to the emergency room, where the admitting physician took photographs of him because his injuries were too extensive to document in writing. Spengler's badge was never recovered (Diedrich 2005b; USA v. Bartlett, Spengler, and Masarik 2009).

The police officers returned to work, and Jude began a slow recovery. But on February 6, 2005, Sunday readers of the Milwaukee Journal Sentinel were met with the following front-page headline: "Police Suspected in Man's Beating" (Diedrich 2005b). Next to the headline was one of the photographs the attending physician had taken of Jude's swollen face. The story told of the beating and the subsequent obstructionism and noncooperation by the police: "Authorities knew right away who was involved, but more than three months later no one has been charged or even arrested." It also listed Jude's injuries: a concussion; broken noise and fractured sinus cavity; cuts in both ears; cuts and swelling to the head, eyes, neck, face, legs, and back; a left eye swollen shut that bled for 10 days; possible permanent disability in one hand; compromised vision; night terrors; and panic attacks.

Citizens, many of them black, took to the streets in protest. Four days after the story broke, more than 100 people marched in front of the District Attorney's office (Nunnally 2005). A month later, nine officers were fired and four others disciplined. All but one appealed and drew their salaries. A year later, Spengler and two fellow officers were tried and acquitted of all charges by an all-white jury (Stingl 2006). More protests followed, prompting a federal investigation. Later that year, eight officers were federally charged. Seven were convicted (Borowski 2007; Diedrich 2007a). 


\title{
DATA AND METHODS
}

\author{
Calls for Service Data
}

We obtained every 911 call placed in Milwaukee between March 1, 2004 and December 31, $2010(N=1,104,369)$. These data, provided by the Milwaukee Police Department (MPD), include the date and address of each call, a city code and description of each call, and a disposition code reporting how the call was resolved. This information allowed us to limit our analysis to police-related calls by dropping those having to do with traffic and vehicular accidents; injuries, fires, and medical emergencies; internal police calls (recovered property, assisting an officer); and calls triggered by security alarms. ${ }^{1}$ Our analyses focus on 911 calls placed the year before and after a given event: for example, we examine police-related calls in 2004 and 2005 when estimating the impact of the Frank Jude beating on citizen crime reporting.

Our analyses draw on all 596 city block groups, the average population of which is roughly 1,000 people. We exclude from our analyses any 911 calls made from block groups beyond Milwaukee city limits, bringing the total number of calls reporting crime to 883,146. We use "neighborhood" and "block group" interchangeably and designate a neighborhood as black or white if these respective groups account for at least two-thirds of neighborhood residents. Last, all crimes recorded by the MPD between 2004 and 2010 were geocoded, aggregated to the block group, and merged with our dataset.

\section{Measures}

Dependent variables. We examine the weekly number of 911 calls at the block-group level. Calls are divided into two categories: total and violent calls. Total calls include all police-related 911 crime reports, not only those for violent and property crime but also reports of public disturbances and nuisances. Calls for violence include those for battery, robbery, weapons/shootings, sexual assault, kidnapping, and threats to person. When attempting to isolate the effect of the beating of Frank Jude on citizen crime reporting, the dependent variable is the number of weekly calls per block group during the observation period: March 2004 to December $2005 .^{2}$ This observation period centers on the date the Milwaukee Journal Sentinel first reported Jude's beating (February 6, 2005), allowing us to analyze roughly the same number of weeks before and after the story broke.

Pre-intervention time trend. Two parameters define the pattern of 911 calls prior to the Sentinel's report of Jude's beating: the initial level of calls and the slope indicating the time trend. The intercept value in our models indicates the estimated number of 911 calls per block group at the beginning of the observation period. The weekly pre-Jude time measure indicates the pre-intervention change in the volume of 911 calls over time (Singer and Willett 2003). Modeling the time trend allows us to establish a counterfactual for what the calling pattern would have been like in the absence of Frank Jude's story. We estimated the pre-intervention time trend with a linear specification as well as a quadratic specification, comparing model fit between specifications using the Bayesian Information Criterion. A linear pre-Jude specification provided a better fit to the data (see Table A1 in the Appendix).

Explanatory variables. To assess the impact of the Jude beating on 911 calling behavior, we test for possible shifts in the level of 911 calls in a block group as well as changes in the slope of the time trend. We do so by including a binary measure equal to 0 for observations prior to the news story of Jude's beating and equal to 1 for the period after the story broke. To measure an interruption in the slope of the time series, we include linear and quadratic time variables, measured as the number of weeks since the story broke. For observations prior to the story, these time variables are set to 0 . As with the pre-intervention time trend, we use model fit 
statistics to assess whether the post-intervention trend is more appropriately modeled with linear or quadratic time specifications (see Table A1). The quadratic post-Jude specification fits best. By including a quadratic term for the post-Jude time period, we are effectively testing for a discontinuous effect of the Jude beating on 911 calls as well as modeling the possibility that 911 calls eventually drift back to the pre-Jude trend.

Fixed effects. We include block-group and month fixed effects in our models. Block-group fixed effects control for all time-invariant block-group-specific factors potentially correlated with 911 calls. Month fixed effects control for seasonal variation in crime and crime reporting, as calls peak in the summer and slump in the winter.

Control variables. To account for the structural characteristics commonly associated with neighborhood-level crime (Land, McCall, and Cohen 1990), we draw on U.S. Census data and calculate the following measures at the block-group level: percent of the population that is nonHispanic black; percent of the population that is Latino; percent of households below the poverty line; and percent of households that rent.

Our models also include weekly crime counts to rule out the possibility that the observed levels of 911 calls are nothing more than an indicator of neighborhood crime levels (Kirk and Matsuda 2011; Klinger 1997). In our models, the control variable reported crime corresponds to the total number of weekly crimes in each block group during the observation period. Derived from aggregate data generated by the Milwaukee Police Department for the FBI's Uniform Crime Report, this variable is organized into two categories: total and violent crimes. When our outcome is all 911 calls, we control for all reported crime during the same week; when it is calls for violence, we control for violent crime. If legal cynicism increased after the media broke the story of Frank Jude's beating, then it is likely that crime also increased during this time period. For the same reason, it is also likely that some crime went unreported to the police (Kirk et al. 2012). If neighborhoods experienced a concomitant increase in crime and decrease in citizen crime reporting, then any negative estimate of the effect of Jude's beating on citizen crime reporting is conservative. In other words, we model a counterfactual 911 calling trend based on pre-Jude calling and crime patterns, but the gap between estimated and counterfactual calling trends is probably larger than we observed because, post-Jude, unreported crime likely increased.

Descriptive statistics are presented in Table 1, which reveals a picture of the city's social, demographic, and crime patterns. In the average Milwaukee neighborhood, there are approximately three 911 calls a week. However, there is wide variation in call levels, ranging from 0 to 41 weekly calls per neighborhood.

\section{$<<<$ Table 1 about here $>>>$}

\section{Methods}

To assess the effect of the Frank Jude beating on citizen crime reporting, we use an interrupted time series design with block-group and month fixed effects. With this design, we assess whether the extensive media coverage of Jude's beating that followed the Sentinel's breaking story induced an interruption in the level and slope of the time series of 911 calls. We use a negative binomial specification to account for the skewness of the 911 calling pattern, with many block groups reporting few or no 911 calls in a given week. We measure exposure as the number of residents in a block group, which we determine from Geolytics annual population estimates.

Previous research suggests that African American communities would be more affected than white communities by the Jude beating (Kirk and Papachristos 2011; Sampson 2012). Hence, in 
addition to analyzing all block groups, we also estimate models separately for black and white neighborhoods. We hypothesize that the effect will be more pronounced in black block groups.

Additionally, we replicate our analyses on the number of weekly calls for automobile accidents, a "nonequivalent dependent variable" that should have been unaffected by the Jude beating (Shadish, Cook, and Campbell 2002:184). Because calls related to car accidents are typically made to report injuries or for insurance purposes, having little to do with trust in law enforcement, we expect them to be unaffected by the incident.

\section{Additional Cases}

To examine if the Frank Jude case was unique, we also investigate if three other cases of police violence against unarmed black men affected citizen crime reporting in Milwaukee. The news reports and court documents on which this section draws are listed at the end of the article.

Danyall Simpson, Milwaukee, Wisconsin; story broke in the local press on February 18, 2007. On May 21, 2006, Danyall Simpson, a 19-year-old black man, was confronted in the driveway of his mother's home by police officer James Langer, a 32-year-old white man. Simpson was suspected of throwing a brick through a neighbor's window. The interaction between Simpson, Langer, and Langer's partner grew confrontational and resulted in Simpson being taken to the ground. While Simpson was lying on his back with his arms pinned, Langer hit him in the face with his flashlight. The blow broke Simpson's eye socket and cheekbone. The Milwaukee Journal Sentinel reported the story on February 18, 2007 (Diedrich 2007b). Readers learned that Langer had a history of using excessive force but was not reprimanded; that it took the MPD three months to deliver the case to the District Attorney's office; and that according to a witness, Langer's hit "sounded as if someone threw a melon in the air and smashed it with a baseball bat." The Sentinel printed a photograph of Simpson's bloodied face.

Sean Bell, Queens, New York; story broke in the national press on November 27, 2006. In the morning hours of November 25, 2006, Sean Bell, a 23-year-old black man due to be married later that day, was shot and killed by New York City police officers. Five plainclothes officers conducting an undercover investigation of a prostitution ring fired over 50 rounds at the car that held Bell and two friends. Bell had been celebrating his last night of bachelorhood at a Queens strip club and was unarmed when killed. The story made national headlines the following day, with coverage in the New York Times, CNN, and other major outlets, eliciting large protests in New York City and beyond (Buckley and Rashbaum 2006; Fransisco, Frieden, and Rose 2006).

Oscar Grant, Oakland, California; story broke in the national press on January 8, 2009. In the first hours of 2009, Oscar Grant III, a 22-year-old black man, was detained on the platform of the Fruitvale Station by Bay Area Rapid Transit police officers, who had received word of a possible fight underway in a crowded train returning from San Francisco. Two officers were attending to Grant, who was lying face down with his hands behind his back, "restrained and unarmed" according to court documents. One of the officers, Johannes Mehserle, a 26-year-old white man, then pulled out his .40 caliber sidearm and shot Grant in the back, puncturing his lung. Grant died the following morning. The incident was recorded by multiple bystanders using portable cameras and disseminated to Internet and media outlets. Protests immediately followed in Oakland, but it took a week for the story to receive widespread coverage in the national press. Mehserle was later found guilty of involuntary manslaughter (Chideya 2009; McKinley 2009).

We selected the Simpson case because it enables us to observe if a local incident of police violence less extreme than Jude's beating also affected citizen crime reporting in Milwaukee. We selected the killings of Sean Bell and Oscar Grant because they were the most nationally publicized cases of police violence that took place during our study period. These two cases 
allow us to investigate if national reports of deadly force used against unarmed black men in other locales had any observable impact on citizen crime reporting in Milwaukee. For each case, we estimate an interrupted time series model with block-group and month fixed effects, as with the Frank Jude case. In contrast to the Frank Jude analyses, model fit statistics revealed that a specification with quadratic time trends for both pre- and post-intervention periods resulted in better model fit.

\section{RESULTS}

We begin by mapping 911 calls against the racial composition of Milwaukee neighborhoods. Figure 1 shows two maps of the city: panel A displays the percent of neighborhood residents who are black; panel B depicts the total number of police-related 911 calls between March 2004 and December 2005. Side-by-side, the maps reveal that predominantly black neighborhoods have higher call volumes. In an average week, residents in black neighborhoods made 5.64 calls to 911 ( $\min .=0$, max. 41), more than triple the calling rate of residents in white neighborhoods $(1.7$ calls per week; $\min .=0, \max .=17)$.

\section{$<<<$ Figure 1 about here $\gg>>$}

Did the Beating of Frank Jude Affect Citizen Crime Reporting?

Table 2 displays the results of negative binomial regression models estimating the relationship between neighborhood characteristics and citizen crime reporting, first for all block groups in the city, then for subsamples of predominately black and white block groups. Model 1 takes as its outcome all 911 calls reporting crime recorded in Milwaukee between March 1, 2004 and December 31, 2005. Model 2 focuses on a subset of calls reporting violent crime. All three models include block-group and month fixed effects, sociodemographic controls, and the number of reported crimes during each observation week.

\section{$<<<$ Table 2 about here $\gg>$}

Looking first at all neighborhoods, the overall trend for total calls (as seen in the weeks pre-Jude story coefficient) is positive and significant, indicating that police-related 911 calls trended slightly upward during the observation period. ${ }^{3}$ The non-significant coefficient for Jude story indicates that the weekly number of 911 calls did not shift abruptly in either direction immediately following the publication of Jude's beating. However, the negative linear postintervention slope trend (weeks post-Jude story) finds that 911 calls for service declined significantly in the period after the story broke. This observed decline is net of controls for reported crime, neighborhood sociodemographic characteristics, and fixed effects for timeinvariant block-group characteristics and month fixed effects for the seasonality of 911 calls. The small, positive quadratic time term reveals that the "Jude effect" diminished over time, with 911 calls eventually returning to expected levels. Calls for violent crime declined significantly following Jude's story before eventually returning to pre-intervention levels.

Figure 2 displays the estimated pattern of 911 calls before and after the press reported Frank Jude's story. We estimated counts using Stata's margins command following the execution of our negative binomial regressions. The dotted line represents a counterfactual calling pattern that extends the pre-Jude time trend into the post-intervention period. It estimates the expected number of 911 calls in the absence of Jude's story. As Figure 2 shows, the number of calls reporting crime declined substantially in the wake of Jude's beating, relative to the counterfactual, and did not return to expected levels for more than a year.

$<<$ Figure 2 about here $>>>$ 
Table 2 also contrasts the estimated effect of the Jude beating in black and white neighborhoods. In tabular form, the results appear similar across neighborhoods. In both subsamples, the change in the intercept (denoted by the coefficient Jude story) is not significant, but the linear post-story trend is significant and negative, with the effect appearing larger in white neighborhoods. The quadratic term is positive but non-significant in the black-neighborhoods subsample but positive and significant in the white-neighborhoods subsample, indicating that the initial decline in calls diminished with time in white but not black neighborhoods.

Figure 3 reveals the benefit of visually displaying these results. In black neighborhoods, the decline in 911 calls is large and durable, with citizen crime reporting dropping and staying lower than expected for over a year after the story broke. In white neighborhoods, by contrast, a small decline in 911 calls followed Jude's story, but the effect dissipated rapidly as 911 calls eventually surpassed the counterfactual line within a year's time. The beating of Frank Jude had a much more substantial effect on citizen crime reporting in black neighborhoods than in white neighborhoods. With respect to reporting violent crime in particular, calls declined temporarily in white but not black neighborhoods after the story broke.

\section{$<<$ Figure 3 about here $>>>$}

Drawing on the results presented in Figures 2 and 3, we calculate a "bottom line" estimate of the total number of police-related 911 calls that were not made in the wake of Milwaukeeans learning of Jude's beating. We do so by summing the difference between the counterfactual time trend and the estimated post-Jude trend across different call types. We estimate that the police beating of Frank Jude resulted in a net loss of approximately 22,200 911 calls reporting crime the year after Jude's story broke. Over half (56 percent) of the total loss in calls occurred in black neighborhoods. For comparison purposes, there were approximately 110,000 policerelated 911 calls from all Milwaukee neighborhoods during this time period.

\section{Calls for Automobile Accidents}

To test whether calls for incidents that should not have been affected by Frank Jude's beating also declined during the observation period, we analyze calls reporting automobile accidents. If we find that calls for accidents declined following Jude's story, we would have reason to be concerned that some other concurrent event besides the beating - for example, reductions in staff capacity at 911 call centers or a local sports team winning the championship —had influenced crime reporting.

As with our previous analyses, we compared model fit to different specifications of the pre- and post-Jude time period, finding that a model with a linear specification for both time periods provided the best fit. As Table 3 shows, 911 calls related to traffic accidents increased during the weeks following Jude's story, net of sociodemographic controls and weather conditions (weekly rainfall and snowfall). ${ }^{4}$ These findings show that the observed decline in police-related 911 calls that followed Jude's story was not a product of a general decline in all 911 calls; rather, the decline was specific to crime reporting.

\section{$\ll<$ Table 3 about here $\gg>$}

\section{Danyall Simpson, Sean Bell, and Oscar Grant}

Having found evidence indicating that the story of Frank Jude's beating depressed citizen crime reporting, particularly in Milwaukee's black neighborhoods, we now investigate whether 911 calls were affected by other cases of police violence against unarmed black men documented in 
the local and national press. We replicate our fixed-effects regression analyses for Danyall Simpson's beating and the fatal shootings of Sean Bell and Oscar Grant. Table 4 displays the results for all neighborhoods and a subsample of black neighborhoods. We focus on the weekly number of 911 calls at the neighborhood level, following the reporting of each incident (for Simpson: February 18, 2007; for Bell: November 27, 2006; for Grant: January 8, 2009). ${ }^{5}$

\section{$\ll<$ Table 4 about here $\gg>$}

Consistent with our findings from the Frank Jude case, 911 calls reporting crime declined significantly following the breaking of Danyall Simpson's beating. Both the level and slope of crime reporting declined. This finding holds when examining calls reporting violent crime. Likewise, citizen crime reporting fell significantly in black neighborhoods after publication of the Simpson beating.

Local incidents of police violence, when publicized in the press, dampen crime reporting in Milwaukee. But could non-local incidents reported in the national press also affect citizen crime reporting? Our findings suggest they do, although not to the extent of local events. After Sean Bell's killing made national headlines, the level of 911 calls declined significantly -in all Milwaukee neighborhoods and in black neighborhoods, particularly - however, we do not observe a significant change in the slope of the post-story time trend. By contrast, the killing of Oscar Grant in Oakland, California, did not result in a decline in police-related 911 calls in Milwaukee. In fact, 911 calls increased in the weeks following Grant's death, a trend that may reflect changes within Milwaukee neighborhoods in the wake of the Great Recession.

In two of our three additional cases, we observed an association between police officers' use of excessive or deadly force against an unarmed black man and fewer crimes reported to the police. The effect of Frank Jude's beating on citizen crime reporting matched the severity of the incident, but instances of police violence less extreme by comparison, as well as events that took place thousands of miles away, still appear to have had an impact on crime reporting in Milwaukee.

\section{DISCUSSION}

Cities across the United States have experienced high-profile cases of excessive use of police force (Holmes and Smith 2008; Ross 2000). Yet little work has been dedicated to understanding their effects on police-community relations. Applying stringent statistical analyses to hundreds of thousands of 911 calls, we sought to identify a relationship between publicized cases of police violence against unarmed black men and citizen crime reporting.

This study shows that publicized cases of police violence against unarmed black men have a clear and significant impact on citizen crime reporting. Once the story of Frank Jude's beating appeared in the press, Milwaukee residents, especially people in black neighborhoods, were less likely to call the police, including to report violent crime. Both white and black citizens' opinions of the police may drop after a high-profile brutality case against unarmed black men (Lasley 1994; Weitzer 2002), but our study found that only people living in black neighborhoods altered their crime-reporting behavior for a significant period of time after the publication of such events. The dampening effect of the Jude beating on citizen crime reporting persisted for months, resulting in a net loss of more than 20,000 911 calls. It is one thing to disparage law enforcement in your thoughts and speech after an instance of police violence or corruption makes the news. It is quite another to witness a crime, or even to be victimized, and refuse to report it.

The events of that October morning affected not only Frank Jude and his family but Black 
Milwaukee as a whole. To date, research has mainly focused on how individuals' personal interactions with law-enforcement officers (Skogan 2006; Tyler and Waslak 2004) or the vicarious experiences of one's social ties (Brunson 2007; Rosenbaum et al. 2005) influence attitudes toward the police. This study, however, shows that in predominantly black neighborhoods, publicized cases of police violence can have a community-wide impact on crime reporting that transcends individual encounters. An important implication of this finding is that publicized cases of police violence not only threaten the legitimacy and reputation of law enforcement; they also - by driving down 911 calls - thwart the suppression of law breaking, obstruct the application of justice, and ultimately make cities as a whole, and the black community in particular, less safe.

To gather empirical support for this line of thought, we examined homicides following the publication of Jude's beating. Unlike with other crime, murder records should not be affected by fluctuations in citizen crime reporting, owing to the gravity and nature of the crime. During the six months that followed Jude's story (March to August 2005), 87 homicides occurred in Milwaukee, representing a 32 percent increase in murders relative to the same six-month period in previous and subsequent years. In fact, as Figure 4 shows, the spring and summer that followed Jude's story were the deadliest in the seven years observed in our study. This uptick in homicides occurred during months in which citizen crime reporting, especially in the black community, fell by significant margins.

\section{$<<<$ Figure 4 about here $\gg \gg>$}

We also found that it does not take a major or local event to reduce crime reporting. Milwaukee residents issued fewer calls for service after the local press reported the assault of Danyall Simpson by a white police officer, an assault less severe than Jude's, and they were less likely to call the police after the killing of Sean Bell (in Queens, New York) made national headlines. We found no evidence, however, that the killing of Oscar Grant (in Oakland, California) lowered crime-reporting behavior in Milwaukee. We found some evidence, then, that highprofile cases of unarmed black men being assaulted or killed by law-enforcement officers may affect citizen crime reporting in cities far removed from the site of the incident.

Our analyses of the Frank Jude beating found that crime reporting eventually returned to typical levels, but it took roughly one year before they did - and even longer in black neighborhoods. Other studies that examine the impact of major, divisive events on attitudes or behavior have observed profound but short-lived effects, characterized by a sharp escalation and an equally sharp de-escalation (King and Sutton 2013; Legewie 2013). The effect of police violence on citizen crime reporting documented in this study is considerably lengthy by comparison. This indicates that high-profile cases of excessive police force constitute a severe breach in the social contract that exists between citizens and the criminal justice system. That breach is so sudden and violent when unarmed black men are beaten or killed that virtually no institutional response, from public apologies to sanctioning offending officers, can swiftly repair it. Crime reporting remained significantly lower in black neighborhoods weeks after officers involved in Jude's beating were charged and fired.

With time, however, citizen crime reporting returned to normal levels. Police have a virtual monopoly on crime control, and alternative forms of law enforcement emerge only under extreme circumstances (see Venkatesh 2000). Accordingly, residents who witness or are victimized by crime have little recourse other than to call 911 , which is perhaps why people negatively disposed toward the police often favor increased law enforcement to promote public safety (Carr et al. 2007; Sampson and Bartusch 1998).

Taken together, our findings present a dynamic, eventful theoretical model that illuminates the 
relationship between economic and racial inequality, legal cynicism, and citizen cooperation with the police. Major episodes of police violence against unarmed black men covered by the press can interface with a general sentiment of legal cynicism within the black community to drive behavior, drawing out action from attitudes.

Our findings demonstrate that the media plays a crucial role in this process, not only by raising awareness of episodes of police violence but also by addressing basic questions about such episodes. What exactly happened? What was the race of the victim and police officer? Was the victim armed? When these questions are addressed, either by professional reporters (as in Frank Jude's case) or "citizen journalists" who video record and broadcast incidents, that narrows the number of reasonable interpretations (Koopmans 2004; Scheufele 1999), allowing certain acts of police force to be seen as unreasonable and disturbing. This can produce widespread effects on citizen crime reporting when large numbers of people learn of an episode around the same time (see Andrews and Biggs 2006).

In the short run, publicized episodes of excessive police violence against unarmed black men can activate legal cynicism within the black community to diminish residents' cooperation with law enforcement. In the long run, such episodes likely contribute to that very cynicism by being incorporated into the community's collective memory. ${ }^{6}$ We believe collective memory explains why we found "the Jude effect" to be particularly strong in black neighborhoods. Such incidents belong to a centuries-old tradition of state-sanctioned assaults on the black body-from slavery and lynching campaigns to urban riots and mass incarceration (Muller 2012; Patterson 1998)an ugly fact that African Americans are more likely to recognize and dread. Against this backdrop, a violent episode carried out by the police is registered as proof and product of a violent heritage, rendering victim and perpetrator actors in a larger historical drama. A survey conducted after a white police officer shot and killed Michael Brown, an 18-year-old black man, in Ferguson, Missouri, found that 80 percent of African Americans believed the case "raises important issues about race," compared to 37 percent of whites (Pew Research Center 2014). Owing to the legacy of racism in the United States, many members of the black community perceive an assault of a black man by white police officers as an assault on the black community writ large, activating a collective response. Within black neighborhoods, the impact of police violence on citizen crime reporting results not only from African Americans identifying with the victim but also interpreting the moment of victimization in terms that articulate the nation's racial heritage. By extension, we would not expect an equivalent response in predominantly white or Latino neighborhoods after publicized episodes of police violence against unarmed white or Latino citizens.

Future research can assess this hypothesis. Because this study relied on administrative records, its findings can be replicated in other locales. In racial composition, population size, and unemployment rate, Milwaukee is similar to many midsize U.S. cities (Desmond, Gershenson, and Kiviat 2015). Like many other urban areas-including cities in which recent well-known cases of police violence have occurred, such as Baltimore, Cleveland, and New York CityMilwaukee has high levels of racial segregation. We might not expect the effect of police violence on citizen crime reporting to be as acute or durable in more integrated cities, a testable expectation. Our findings can also be extended by investigations of how police maltreatment of Hispanic victims may affect citizen crime reporting in Hispanic communities, where legal cynicism is less pronounced than in black neighborhoods (Kirk et al. 2012).

Police departments and city politicians often frame a publicized case of police violence against an unarmed black man as an "isolated incident." If it is determined that the officer abused his authority, the officer is typically presented as a "bad apple" and may be suspended, fired, or arraigned (Kish-Gephart, Harrison, and Treviño 2010; Lersch and Mieczkowski 2005). These steps may be an appropriate way of responding to individual actors, but they may not be 
sufficient to repair the damage done to the black community as a whole. The findings of this study promote a more sociological view of the issue by suggesting that no act of police violence is an isolated incident, in both cause and consequence. Episodes of police wrongdoing are one ramification of a broader trend within the criminal justice system that in recent decades has promoted aggressive law enforcement and severe sentencing. The effect of this trend on crime reduction has been underwhelming (Travis, Western, and Redburn 2014), and some policies and practices have brought about opposite-than-intended effects by making crime worse. In undermining public safety efforts by dampening citizen crime reporting and inviting legal cynicism, police violence is a clear example of this.

Individual instances of institutional failure can have aggregate and lasting consequences that vitiate police-community relations and thwart crime-reduction efforts. If acts of excessive police force result in community-level consequences-including the non-reporting of crime, which by undermining public safety efforts likely contributes to pessimism about law enforcement's effectiveness - then police departments may consider implementing community-level interventions in the aftermath of such acts.

In recent years, city politicians and law enforcement agencies have devoted significant attention and resources to what has come to be known as the "stop snitching" culture. In disadvantaged neighborhoods, noncooperation with the police is often attributed to street culture or fear of retaliation (Brown 2007; Natapoff 2009). In some cases that fear is justified, but one implication of this study is that should we wish to understand why some crime goes unreported in the black community, we should try to understand residents' collective memory regarding police violence in their city and others.

\section{APPENDIX}

Table A1. Model Fit Statistics for Frank Jude Analyses: All Neighborhoods

\begin{tabular}{lrr} 
& & \multicolumn{2}{c}{ Bayesian Information Criterion } \\
\cline { 2 - 3 } Model & Total Calls & Violent Calls \\
\hline Linear Pre- and Post-Jude & $208,328.2$ & $117,140.4$ \\
Linear Pre-Jude and Linear + Quadratic Post-Jude & $208,325.2$ & $117,138.9$ \\
Linear + Quadratic Pre-Jude and Linear Post-Jude & $208,337.9$ & $117,144.8$ \\
Linear + Quadratic Pre-Jude and Linear + Quadratic Post-Jude & $208,331.3$ & $117,137.0$ \\
\hline
\end{tabular}

\section{Acknowledgments}

We thank Javier Auyero, Monica Bell, Lawrence Bobo, John Diedrich, Felix Elwert, Peter HartBrinson, Ryan King, Nikki Jones, Christopher Muller, Devah Pager, and Christopher Wildeman for helpful comments; Jeffrey Blossom for geocoding expertise; Deborah De Laurell and Elizabeth Roberto for research assistance; and the Milwaukee Police Department for supplying data. Earlier drafts of this paper were presented at the Workshop on Violence at the Urban Margins, University of Texas at Austin, April 4, 2013, and the American Sociological Association Annual Meeting, New York City, August 12, 2013.

\section{Funding}

This research was supported by Harvard University.

\section{Notes}

1. The MPD redacted addresses from 2.7 percent of 911 calls having to do with crimes against children and suicides. We dropped these calls, along with calls having to do with commercerelated crime (e.g., shoplifting, forgery). 
2. The City of Milwaukee implemented a new 911 reporting system in early 2004. Because recorded calls during the implementation period are potentially undercounted, we excluded calls placed during the first two months of 2004.

3. Supplemental models (available upon request) examined 911 calling patterns in Jude's neighborhood and adjacent neighborhoods directly after the beating, finding no significant effects on call patterns. At the time of his beating, Jude lived in a majority-white neighborhood on the far south side of the city.

4. We obtained weekly rainfall and snowfall data from the National Oceanic and Atmospheric Administration.

5. Following the procedure used to estimate the effect of Frank Jude's beating on citizen crime reporting, the observation periods for our analyses of these additional cases were centered on the date the news reported on them. Thus the observation period in which we observe crime and 911 calls runs from January 1, 2006 to December 31, 2008 for the Simpson case; from January 1, 2005 to December 31, 2007 for the Bell case; and from January 1, 2008 to December 31, 2010 for the Grant case.

6. For an extended discussion about the interaction between major events and entrenched beliefs and prejudices, see Legewie (2015).

\section{Newspaper and Court Documents}

Associated Press. 2009. "Police Crack Down after Train Shooting Protests, Businesses Smashed, Cars Set Blaze in Oakland after Transit Cop Killed Man.” January 8.

Barton, Gina. 2006. "2 Plead Guilty in Federal Jude Case.” Milwaukee Journal Sentinel, November 4.

Board of Fire and Police Commissioners of the City of Milwaukee. 2008. In the Matter of the Appeal of Police Officer Zoe Jackson from MPD Personnel Order Number 2007-184, March 5.

Borowski, Greg. 2007. “2nd Jude Trail Stands as a Rarity.” Milwaukee Journal Sentinel, July 28.

Buckley, Cara, and William Rashbaum. 2006. “A Day after a Fatal Shooting, Questions, Mourning, and Protest.” New York Times, November 27.

Chideya, Farai. 2009. "Hundreds Protest in Oakland over BART Shooting." National Public Radio, January 8.

CNN. 2007. "Police Fire 50 Rounds, Kill Groom on Day of Wedding." November 26.

Diedrich, John. 2005a. "8 More Fired in Jude Case.” Milwaukee Journal Sentinel, May 24.

Diedrich, John. 2005b. "Police Suspected in Man's Beating." Milwaukee Journal Sentinel, February 6.

Diedrich, John. 2007a. “3 Ex-Officers Guilty.” Milwaukee Journal Sentinel, July 27.

Diedrich, John. 2007b. “Force Blurs the Line.” Milwaukee Journal Sentinel, February 18.

Diedrich, John. 2012. “City Reaches Tentative Settlement in Jude Lawsuit.” Milwaukee Journal 
Sentinel, January 20.

Fransisco, Stacey, Terry Frieden, and Ellen Rose. 2006. "N.Y. Mayor Meets with Dead Groom's Family." CNN, November 29.

McKinley, Jesse. 2009. “Oakland Turns Violent Over Shooting.” New York Times, January 7.

McLaughlin, Eliott, Augie Martin, Dan Simon, and Mallory Simon. 2009. "Hundreds Demand Answers, Action in Subway Shooting." CNN, January 8.

Milwaukee Journal Sentinel. 2007. “Timeline of Events in Frank Jude Beating Case.” July 27.

Milwaukee Journal Sentinel. 2012. "Timeline: Deaths in Milwaukee Police Custody, Proposed Reforms." October 27.

Nunnally, Derrick. 2005. "100 Protest Progress of Police Beating Case.” Milwaukee Journal Sentinel, February 11.

Stingl, Jim. 2006. “Jude Case Plays out Like a Tragedy.” Milwaukee Journal Sentinel, April 16.

USA v. Bartlett, Spengler, and Masarik. 2009. Appeals from the United States District Court for the Eastern District of Wisconsin. No. 06-CR-273, June 8.

Wilson, Michael. 2006. "50 Shots Fired, and the Experts Offer a Theory." New York Times, November 27.

\section{References}

Anderson, Elijah. 1999. Code of the Street: Decency, Violence, and the Moral Life of the Inner City. New York City: Norton.

Andrews, Kenneth, and Michael Biggs. 2006. "The Dynamics of Protest Diffusion: Movement Organizations, Social Networks, and News Media in the 1960 Sit-Ins." American Sociological Review 71(5):752-77.

Avakame, Edem, James Fyfe, and Candace McCoy. 1999. "'Did You Call the Police? What Did They Do?' An Empirical Assessment of Black's Theory of Mobilization of Law.” Justice Quarterly 16(4):765-92.

Banton, Michael. 1964. The Policeman in the Community. New York: Basic Books.

Baumer, Eric. 2002. "Neighborhood Disadvantage and Police Notification by Victims of Violence." Criminology 40(3):579-616.

Black, Donald. 1970. "The Production of Crime Rates.” American Sociological Review 35(4):733-48.

Bobo, Lawrence, and Victor Thompson. 2006. "Unfair by Design: The War on Drugs, Race, and the Legitimacy of the Criminal Justice System." Social Research 73(2):445-72.

Brown, Ethan. 2007. Snitch: Informants, Cooperators, and the Corruption of Justice. New York: PublicAffairs.

Brunson, Rod. 2007. “'Police Don’t Like Black People’: African-American Young Men’s 
Accumulated Police Experiences.” Criminology and Public Policy 6(1):71-102

Brunson, Rod, and Jody Miller. 2006. "Young Black Men and Urban Policing in the United States.” British Journal of Criminology 46(4):613-40.

Carr, Patrick, Laura Napolitano, and Jessica Keating. 2007. "We Never Call the Cops and Here Is Why: A Qualitative Examination of Legal Cynicism in Three Philadelphia Neighborhoods." Criminology 45(2):445-80.

Desmond, Matthew, Carl Gershenson, and Barbara Kiviat. 2015. "Forced Relocation and Residential Instability among Urban Renters.” Social Service Review 89(2):227-62.

Holmes, Malcolm D., and Brad W. Smith. 2008. Race and Police Brutality: Roots of an Urban Dilemma. Albany: SUNY Press.

Jefferis, Eric, Robert Kaminski, Stephen Holmes, and Dena Hanley. 1997. "The Effect of a Videotaped Arrest on Public Perceptions of Police Use of Force." Journal of Criminal Justice 25(5):381-95.

King, Ryan D., and Gretchen M. Sutton. 2013. "High Times for Hate Crimes: Explaining the Temporal Clustering of Hate-Motivated Offending." Criminology 51(4):871-94.

Kirk, David, and Mauri Matsuda. 2011. "Legal Cynicism, Collective Efficacy, and the Ecology of Arrest.” Criminology 49(2):443-72.

Kirk, David, and Andrew Papachristos. 2011. "Cultural Mechanisms and the Persistence of Neighborhood Violence.” American Journal of Sociology 116(4):1190-1233.

Kirk, David, Andrew Papachristos, Jeffrey Fagan, and Tom R. Tyler. 2012. "The Paradox of Law Enforcement in Immigrant Communities: Does Tough Immigration Enforcement Undermine Public Safety?" Annals of the American Academy of Political and Social Science 641(1):79-98.

Kish-Gephart, Jennifer, David Harrison, and Linda Klebe Treviño. 2010. "Bad Apples, Bad Cases, and Bad Barrels: Meta-Analytic Evidence about Sources of Unethical Decisions at Work." Journal of Applied Psychology 95(1):1-31.

Klinger, David. 1997. "Negotiating Order in Patrol Work: An Ecological Theory of Police Response to Deviance.” Criminology 35(2):277-306.

Koopmans, Ruud. 2004. "Movements and Media: Selection Processes and Evolutionary Dynamics in the Public Sphere." Theory and Society 33(3):367-91.

Land, Kenneth C., Patricia L. McCall, and Lawrence E. Cohen. 1990. "Structural Covariates of Homicide Rates: Are There Any Invariances across Time and Social Space?" American Journal of Sociology 95(4):922-63.

Lasley, James. 1994. "The Impact of the Rodney King Incident on Citizen Attitudes toward Police." Policing and Society 3(4):245-55.

Legewie, Joscha. 2013. "Terrorist Events and Attitudes toward Immigrants: A Natural Experiment.” American Journal of Sociology 118(5):1199-1245. 
Legewie, Joscha. 2015. "Racial Profiling and Use of Force in Police Stops: How Local Events Trigger Periods of Increased Discrimination.” Working paper, New York University.

Lersch, Kim Michelle, and Tom Mieczkowski. 2005. "Violent Police Behavior: Past, Present, and Future Research Directions." Aggression and Violent Behavior 10(5):552-68.

Manning, Peter. 1988. Symbolic Communication: Signifying Calls and the Police Response.

Cambridge, MA: MIT Press.

Matulia, Kenneth. 1982. A Balance of Forces: National Survey of Police Deadly Force. Gaithersburg, MD: International Association of Chiefs of Police.

Muller, Christopher. 2012. "Northward Migration and the Rise of Racial Disparity in American Incarceration, 1880-1950.” American Journal of Sociology 118(2):281-326.

Natapoff, Alexandra. 2009. Snitching: Criminal Informants and the Erosion of American Justice. New York: New York University Press.

Patterson, Orlando. 1998. Rituals of Blood: Consequences of Slavery in Two American Centuries. New York: Basic Civitas Books.

Pew Research Center. 2012. "News about Trayvon Martin Cast Still Top Story." Washington, DC: Pew Research Center for People and the Press.

Pew Research Center. 2014. "Stark Racial Divisions in Reactions to Ferguson Police Shooting." Washington, DC: Pew Research Center for People and the Press.

Reiss, Albert, Jr. 1992. "Police Organization in the Twentieth Century." Crime and Justice 15:51-97.

Rosenbaum, Dennis, Amie Schuck, Sandra Costello, Darnell Hawkins, and Marianne Ring. 2005. "Attitudes toward the Police: The Effects of Direct and Vicarious Experience." Police Quarterly 8(3):343-65.

Rosenfeld, Richard, Bruce Jacobs, and Richard Wright. 2003. "Snitching and the Code of the Street.” British Journal of Criminology 43(2):291-309.

Ross, Jeffrey Ian. 2000. Making News of Police Violence: A Comparative Study of Toronto and New York. Westport, CT: Praeger.

Sampson, Robert. 2012. Great American City: Chicago and the Enduring Neighborhood Effect. Chicago: University of Chicago Press.

Sampson, Robert, and Jeglum Bartusch. 1998. "Legal Cynicism and (Subcultural?) Tolerance of Deviance: The Neighborhood Context of Racial Differences." Law and Society Review 32(4):777-804.

Sánchez Jankowski, Martín. 1991. Islands in the Street: Gangs and American Urban Society. Berkeley and Los Angeles: University of California Press.

Scheufele, Dietram. 1999. "Framing as a Theory of Media Effects." Journal of Communication 49(1):103-122. 
Shadish, William, Thomas Cook, and Donald Campbell. 2002. Experimental and QuasiExperimental Designs for Generalized Causal Inference. Independence, KY: Wadsworth Cengage Learning.

Singer, Judith, and John Willett. 2003. Applied Longitudinal Data Analysis: Modeling Change and Event Occurrence. New York: Oxford University Press.

Skogan, Wesley. 2006. "Asymmetry in the Impact of Encounters with the Police." Policing and Society 16(2):99-126.

Terrill, William, and Michael Reisig. 2003. "Neighborhood Context and Police Use of Force." Journal of Research on Crime and Delinquency 40(3):291-321.

Travis, Jeremy, Bruce Western, and Steve Redburn, eds. 2014. The Growth of Incarceration in the United States: Exploring Causes and Consequences. Washington, DC: National Academies Press.

Tyler, Tom R., and Cheryl Waslak. 2004. "Profiling and Police Legitimacy: Procedural Justice, Attributions of Motive, and Acceptance of Police Authority." Criminology 42(2):253-81.

Venkatesh, Sudhir. 2000. American Project: The Rise and Fall of a Modern Ghetto. Cambridge, MA: Harvard University Press.

Weitzer, Ronald. 2002. "Incidents of Police Misconduct and Public Opinion." Journal of Criminal Justice 30(5):397-408.

Weitzer, Ronald, and Steven Tuch. 2005. "Racially Biased Policing: Determinants of Citizen Perceptions.” Social Forces 83(3):1009-30.

Worden, Robert. 1996. "The Causes of Police Brutality: Theory and Evidence on Police Use of Force.” Pp. 23-51 in Police Violence: Understanding and Controlling Police Abuse of Force, edited by W. Geller and H. Toch. New Haven, CT: Yale University Press.

Matthew Desmond is the John L. Loeb Associate Professor of the Social Sciences and the CoDirector of the Justice and Poverty Project at Harvard University. A sociologist of urban poverty, racial inequality, housing insecurity, and public policy, his latest book is Evicted: Poverty and Profit in the American City.

Andrew V. Papachristos is an Associate Professor in the Department of Sociology at Yale University. His research examines neighborhood social organization, street gangs, interpersonal violence, illegal gun markets, and social networks. He is currently completing a multicity study on the diffusion of gun violence within high-risk social networks.

David S. Kirk is Associate Professor in the Department of Sociology and a Professorial Fellow of Nuffield College at the University of Oxford. For more than a decade he has been examining the consequences of the forced migration from Hurricane Katrina on the lives of former Louisiana prisoners. One extension to this work involves an experimental housing mobility program for ex-prisoners. Kirk's recent research has appeared in the Proceedings of the National Academy of Sciences, Criminology, Social Problems, and American Journal of Epidemiology. 
Table1. Summary Statistics for Population, Call, and Crime Variables

\begin{tabular}{lcccc}
\hline & Mean & SD & Min. & Max. \\
\hline Neighborhood Structural Variables & & & & \\
$\quad$ Percent Black & .392 & .370 & 0 & .990 \\
Percent Latino & .113 & .183 & 0 & .828 \\
Percent Poverty & .203 & .154 & 0 & .817 \\
$\quad$ Percent Renter & .533 & .225 & 0 & 1 \\
Weekly Calls for Service & & & & \\
$\quad$ Total & 3.367 & 3.565 & 0 & 41 \\
$\quad$ Violence & .898 & 1.437 & 0 & 17 \\
Weekly Reported Crimes & & & & \\
$\quad$ Total Crimes & 1.823 & 1.950 & 0 & 35 \\
$\quad$ Violent Crimes & .403 & .753 & 0 & 9 \\
\hline
\end{tabular}

Note: Summary data for 596 Milwaukee block groups. Here, crime and 911 call statistics pertain to the observation period before and after the newspaper broke the story of Frank Jude's beating: March 1, 2004 to December 31, 2005. 
Table 2. Negative Binomial Regressions with Neighborhood and Month Fixed Effects Estimating the Effect of Frank Jude's Beating on Citizen Crime Reporting: All, Black, and White Neighborhoods

\begin{tabular}{|c|c|c|c|c|c|c|}
\hline & \multicolumn{2}{|c|}{ All Neighborhoods } & \multicolumn{2}{|c|}{ Black Neighborhoods } & \multicolumn{2}{|c|}{ White Neighborhoods } \\
\hline & Total Calls & Violent Calls & Total Calls & Violent Calls & Total Calls & Violent Calls \\
\hline \multirow[t]{2}{*}{ Intercept } & $-6.378^{* * *}$ & $-7.876^{* * *}$ & $-6.436^{* * *}$ & $-7.594 * * *$ & $-6.679 * * *$ & $-8.574 * * *$ \\
\hline & $(.087)$ & $(.140)$ & $(.418)$ & $(.538)$ & $(.173)$ & $(.348)$ \\
\hline \multirow[t]{2}{*}{ Weeks Pre-Jude Story } & $.036 * * *$ & .019 & $.031 * *$ & -.007 & $.044 *$ & .037 \\
\hline & $(.008)$ & $(.015)$ & $(.011)$ & $(.020)$ & $(.022)$ & $(.051)$ \\
\hline \multirow[t]{2}{*}{ Jude Story } & -.009 & -.021 & -.005 & .036 & .114 & .005 \\
\hline & $(.034)$ & $(.065)$ & $(.048)$ & $(.089)$ & $(.095)$ & $(.224)$ \\
\hline \multirow[t]{2}{*}{ Weeks Post-Jude Story } & $-.088 * * *$ & $-.117 * *$ & $-.069 *$ & -.019 & $-.192 * *$ & $-.281 *$ \\
\hline & $(.021)$ & $(.040)$ & $(.030)$ & $(.053)$ & $(.061)$ & $(.137)$ \\
\hline \multirow{2}{*}{ Weeks Post-Jude Story (squared) } & $.002 * * *$ & $.003 * * *$ & .001 & .000 & $.004 * * *$ & $.008 * *$ \\
\hline & $(.000)$ & $(.001)$ & $(.001)$ & $(.001)$ & $(.001)$ & $(.003)$ \\
\hline \multirow[t]{2}{*}{ Reported Crime } & $.039 * * *$ & $.202 * * *$ & $.037 * * *$ & $.171 * * *$ & $.036^{* * *}$ & $.465 * * *$ \\
\hline & $(.002)$ & $(.005)$ & $(.002)$ & $(.006)$ & $(.004)$ & $(.023)$ \\
\hline \multirow{2}{*}{ Percent Poverty } & $.999 * * *$ & $1.338 * * *$ & $1.087 * *$ & $2.000 * * *$ & 1.733 & 2.736 \\
\hline & $(.224)$ & $(.299)$ & $(.330)$ & $(.422)$ & $(1.113)$ & (1.706) \\
\hline \multirow[t]{2}{*}{ Percent Renter } & $.314^{*}$ & $.547 * *$ & -.166 & -.304 & .550 & $1.107 * *$ \\
\hline & $(.150)$ & $(.209)$ & $(.294)$ & $(.367)$ & $(.295)$ & $(.424)$ \\
\hline \multirow[t]{2}{*}{ Percent Black } & $1.030 * * *$ & $1.353 * * *$ & $1.330 * *$ & $1.511 * *$ & $2.369^{* *}$ & 1.797 \\
\hline & $(.092)$ & $(.130)$ & $(.437)$ & $(.549)$ & $(.857)$ & (1.122) \\
\hline \multirow{2}{*}{ Percent Latino } & $.634 * * *$ & $.919 * * *$ & 2.775 & 1.159 & .907 & .685 \\
\hline & $(.158)$ & $(.219)$ & (1.502) & (1.694) & (1.050) & (1.520) \\
\hline
\end{tabular}

Note: These models focus on the observation period of March 1, 2004 to December 31, 2005. The reported crime variable represents all reported weekly crimes when the outcome is total police-related 911 calls and violent crimes when the outcome is calls reporting violence. Black/white neighborhoods are defined as those in which at least 65 percent of residents are black/white. Coefficients and standard errors (in parentheses) for the week measures of time were multiplied by 10 for ease of interpretation. $N$ $=596$ neighborhoods.

$* p<.05 ; * *<.01 ; * * * p<.001$ (two-tailed test) 
Table 3. Nonequivalent Dependent Variable Models Estimating the Effect of

Frank Jude's Beating on Calls for Automobile Accidents

\begin{tabular}{lc}
\hline & Accident Calls \\
\hline Intercept & $-8.371^{* * *}$ \\
& $(.287)$ \\
Weeks Pre-Jude Story & -.004 \\
& $(.003)$ \\
Jude Story & -.128 \\
& $(.165)$ \\
Weeks Post-Jude Story & $.016^{* * *}$ \\
& $(.003)$ \\
Percent Poverty & .315 \\
& $(.597)$ \\
Percent Renter & $1.116^{* *}$ \\
& $(.387)$ \\
Percent Black & -.303 \\
& $(.229)$ \\
Percent Latino & -.663 \\
& $(.358)$ \\
Weekly Rainfall & .031 \\
& $(.023)$ \\
Weekly Snowfall & $.051^{* * *}$ \\
& $(.012)$ \\
\hline
\end{tabular}

Note: $N=596$ neighborhoods. Standard errors are in parentheses.

$* p<.05 ; * * p<.01 ; * * * p<.001$ (two-tailed test). 
Table 4. Negative Binomial Regressions with Neighborhood and Month Fixed Effects Estimating the Effect of the Danyall Simpson, Sean Bell, and Oscar Grant Stories on Citizen Crime Reporting: All and Black Neighborhoods

Intercept

Weeks Pre-Story

Weeks Pre-Story (squared)

Story

Weeks Post-Story

Weeks Post-Story (squared)

Reported Crime

Percent Poverty

Percent Renter

Percent Black

Percent Latino

\begin{tabular}{|c|c|}
\hline \multicolumn{2}{|c|}{ Danyall Simpson } \\
\hline Total Calls & Violent Calls \\
\hline$-4.116 * * *$ & $-5.333 * * *$ \\
\hline$(, 311)$ & $(.579)$ \\
\hline$-.221 * * *$ & $-.293 * *$ \\
\hline$(.047)$ & $(.089)$ \\
\hline $.001 * * *$ & $.001 * *$ \\
\hline$(.000)$ & $(.000)$ \\
\hline$-.032 *$ & -.041 \\
\hline$(.015)$ & $(.028)$ \\
\hline-.014 & $-.062 * *$ \\
\hline$(.011)$ & $(.020)$ \\
\hline$-.001 * * *$ & $-.001 * * *$ \\
\hline$(.000)$ & $(.000)$ \\
\hline $.053^{* * *}$ & $.231 * * *$ \\
\hline$(.001)$ & $(.003)$ \\
\hline .294 & .208 \\
\hline$(.176)$ & $(.214)$ \\
\hline $.348 * *$ & $.835 * * *$ \\
\hline$(.116)$ & $(.154)$ \\
\hline $.892 * * *$ & $1.192 * * *$ \\
\hline$(.075)$ & $(.095)$ \\
\hline $.402 * *$ & $.690 * * *$ \\
\hline$(.127)$ & $(.163)$ \\
\hline
\end{tabular}

\begin{tabular}{cc}
\multicolumn{2}{c}{ Sean Bell } \\
\cline { 1 - 2 } Total Calls & Violent Calls \\
\cline { 1 - 2 } All Neighborhoods & $-7.737^{* * *}$ \\
$-6.386^{* * *}$ & $(.115)$ \\
$(.070)$ & $.061^{* * *}$ \\
$.093^{* * *}$ & $(.015)$ \\
$(.008)$ & -.000 \\
$-.000^{* * *}$ & $(.000)$ \\
$(.000)$ & $-.152^{* * *}$ \\
$-.090^{* * *}$ & $(.030)$ \\
$(.016)$ & .009 \\
.014 & $(.021)$ \\
$(.011)$ & -.001 \\
.000 & $(.000)$ \\
$(.000)$ & $.229^{* * *}$ \\
$.049^{* * *}$ & $(.003)$ \\
$(.001)$ & .443 \\
$.596^{* *}$ & $(.239)$ \\
$(.179)$ & $.745^{* * *}$ \\
$.348^{* *}$ & $(.172)$ \\
$(.118)$ & $1.236^{* * *}$ \\
$.965^{* * *}$ & $(.106)$ \\
$(.076)$ & $.718^{* * *}$ \\
$.478^{* * *}$ & $(.180)$ \\
$(.128)$ &
\end{tabular}

$\frac{\text { Total Calls }}{-12.532 * * *}$
Oscar Grant

$(1.141)$

$.629 * * *$
$(.098)$

$-.001 * * *$

$(.000)$
$167 * * *$

(.015)

$.061^{* * *}$

(.012)

(.000)

$.056^{* * * *}$

$.056^{* * * *}$
$(.001)$

$-.003$

(.161)

.150

(.103)

$.939 * * *$

(.069)

(.113)

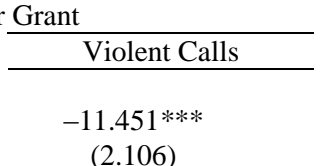

.344

(.181)

$-.001$

(.000)

.022

(.028)

$.047 *$

$.047 *$
$(.022)$

.001

(.000)

$.244 * * *$

$.244 * 3)$
.041

(.197)

$853 * * *$

$(.135)$
$1.328 * * *$

(.087)

(.148)

\begin{tabular}{|c|c|c|c|c|c|c|}
\hline \multirow[b]{2}{*}{ Intercept } & \multicolumn{6}{|c|}{ Black Neighborhoods } \\
\hline & $\begin{array}{c}-5.980 * * * \\
(.535)\end{array}$ & $\begin{array}{c}-5.685 * * * \\
(.867)\end{array}$ & $\begin{array}{c}-7.012 * * * \\
(.327)\end{array}$ & $\begin{array}{c}-7.587 * * * \\
(.440)\end{array}$ & $\begin{array}{c}-12.874 * * * \\
(1.700)\end{array}$ & $\begin{array}{c}-17.424 * * * * \\
(2.932)\end{array}$ \\
\hline Weeks Pre-Story & $\begin{array}{l}-.098 \\
(.068)\end{array}$ & $\begin{array}{c}-.247 * \\
(.121)\end{array}$ & $\begin{array}{c}.080 * * * \\
(.011)\end{array}$ & $\begin{array}{c}.070 * * * \\
(.020)\end{array}$ & $\begin{array}{l}.634 * \\
(.144)\end{array}$ & $\begin{array}{l}.863 * * \\
(.025)\end{array}$ \\
\hline Weeks Pre-Story (squared) & $\begin{array}{c}.000 \\
(.000)\end{array}$ & $\begin{array}{l}.001 \\
. .000)\end{array}$ & $\begin{array}{c}-.000 * * * \\
(.000)\end{array}$ & $\begin{array}{l}-.000 \\
(.000)\end{array}$ & $\begin{array}{c}-.001 * * * \\
(.000)\end{array}$ & $\begin{array}{c}-.002 * * * \\
(.001)\end{array}$ \\
\hline Story & $\begin{array}{l}-.029 \\
(.022)\end{array}$ & $\begin{array}{l}-.034 \\
(.039)\end{array}$ & $\begin{array}{c}-.056^{*} \\
(.023)\end{array}$ & $\begin{array}{c}-.108 * * \\
(.041)\end{array}$ & $\begin{array}{l}.201 \\
(.023)\end{array}$ & $\begin{array}{l}.074 \\
(.039)\end{array}$ \\
\hline Weeks Post-Story & $\begin{array}{l}.031 * \\
(.016)\end{array}$ & $\begin{array}{l}-.032 \\
(.028)\end{array}$ & $\begin{array}{l}-.029 \\
(.017)\end{array}$ & $\begin{array}{l}-.022 \\
(.029)\end{array}$ & $\begin{array}{l}.070 * * \\
(.018)\end{array}$ & $\begin{array}{c}.108 * * * * \\
(.031)\end{array}$ \\
\hline Weeks Post-Story (squared) & $\begin{array}{c}-.001 * * \\
(.000)\end{array}$ & $\begin{array}{c}-.001^{*} \\
(.000)\end{array}$ & $\begin{array}{l}.001 * * \\
(.000)\end{array}$ & $\begin{array}{l}.000 \\
(.000)\end{array}$ & $\begin{array}{c}.002 * * * \\
(.000)\end{array}$ & $\begin{array}{c}.002 * * * \\
(.001)\end{array}$ \\
\hline Reported Crime & $\begin{array}{c}.049 * * * \\
(.001)\end{array}$ & $\begin{array}{c}.185 * * * \\
(.004)\end{array}$ & $\begin{array}{c}.045 * * * \\
(.001)\end{array}$ & $\begin{array}{c}.186 * * * \\
(.004)\end{array}$ & $\begin{array}{c}.055^{* * * *} \\
(.002)\end{array}$ & $\begin{array}{c}.196 * * * \\
(.004)\end{array}$ \\
\hline Percent Poverty & $\begin{array}{l}.346 \\
(.266)\end{array}$ & $\begin{array}{l}.111 \\
(.315)\end{array}$ & $\begin{array}{l}.798 * * \\
(.273)\end{array}$ & $\begin{array}{l}.687^{*} \\
(.346)\end{array}$ & $\begin{array}{l}.122 \\
(.242)\end{array}$ & $\begin{array}{l}.417 \\
(.287)\end{array}$ \\
\hline Percent Renter & -.176 & 467 & -.036 & .351 & .023 & .309 \\
\hline
\end{tabular}




\section{Percent Black}

(.229)

$2.477 * * *$

Percent Latino

2.323*

$(.293)$
$1.717 * * *$

$1.717 * * *$

(.239)

$1.895 * * *$

$(1.045)$

.049

(.353)
$2.840 *$

(1.220)

$(1.220)$

Note: The reported crime variable represents all reported weekly crimes when the outcome is total police-related 911 calls and viole

Black neighborhoods are defined as those in which at least 65 percent of residents are black. Coefficients and standard errors (in parentheses) for the week measures of time were multiplied by 10 for ease of interpretation. $N=596$ neighborhoods.

$* p<.05 ; * * p<.01 ; * * * p<.001$ (two-tailed test). 


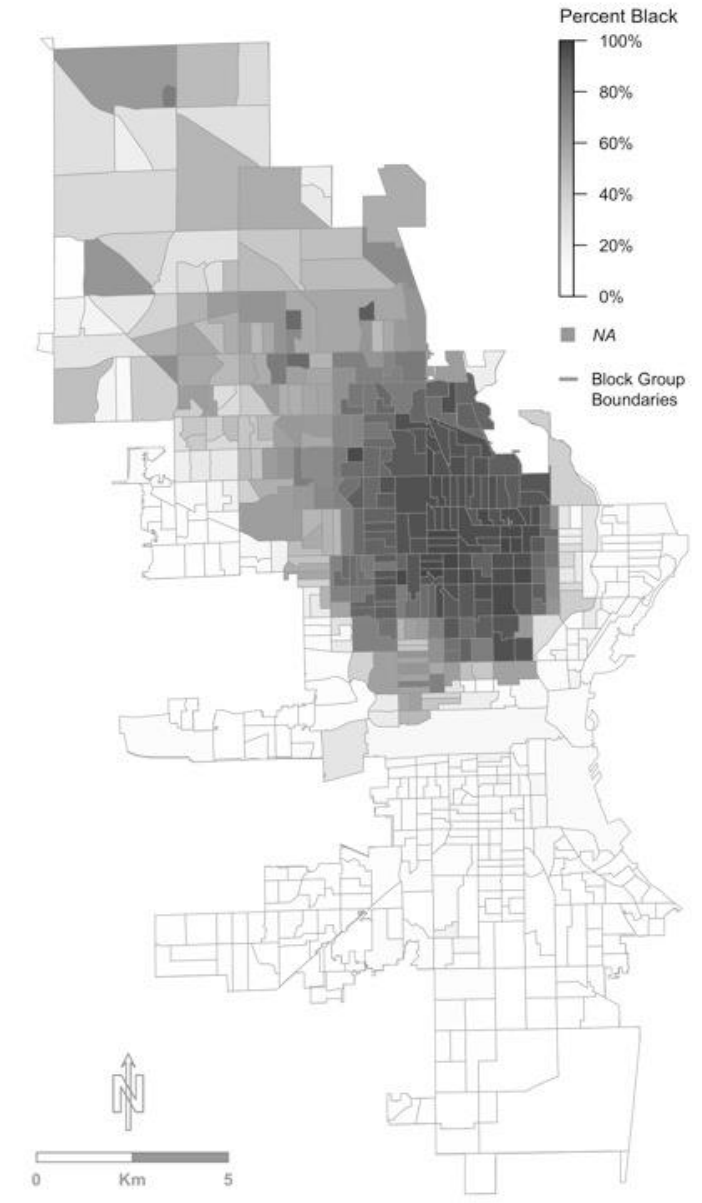

(A)

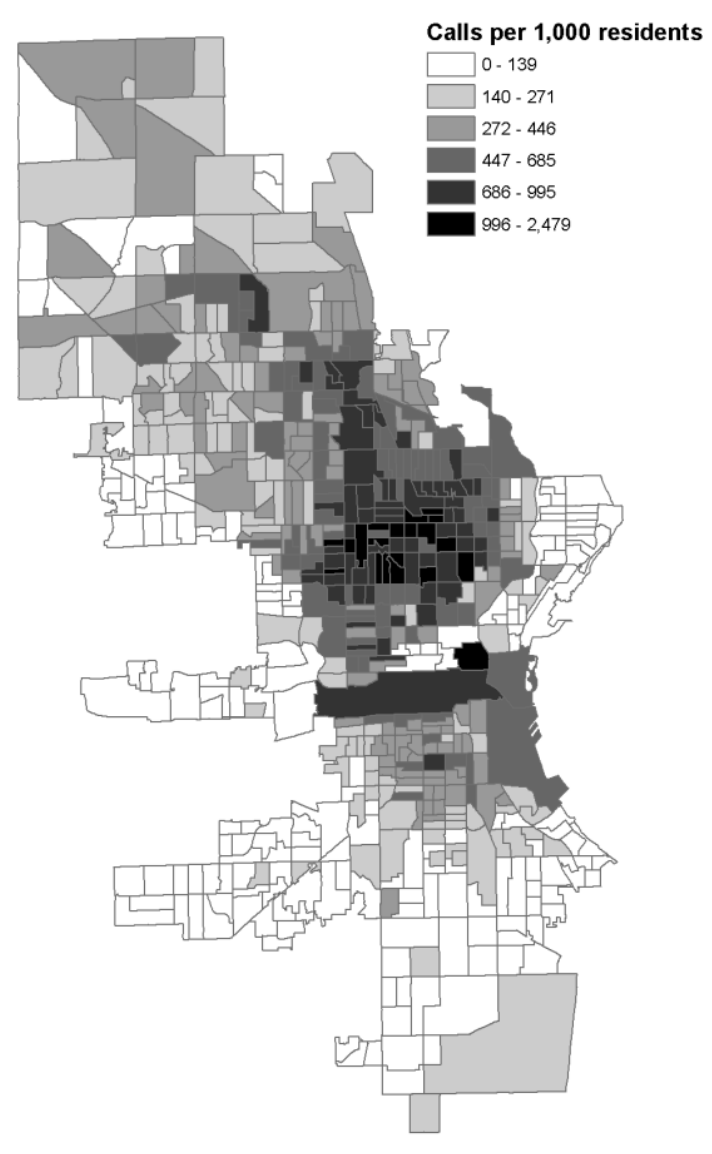

(B)

Figure 1. Milwaukee Maps Showing (A) the Percent of Neighborhood Residents Who Are Black and (B) the Total Number of Police-Related 911 Calls: March 2004 to December 2005

Note: Darker shading indicates a larger percentage of black residents or a higher 911 calling rate. 
Estimated Calls $\cdots \cdots$ Counterfactual

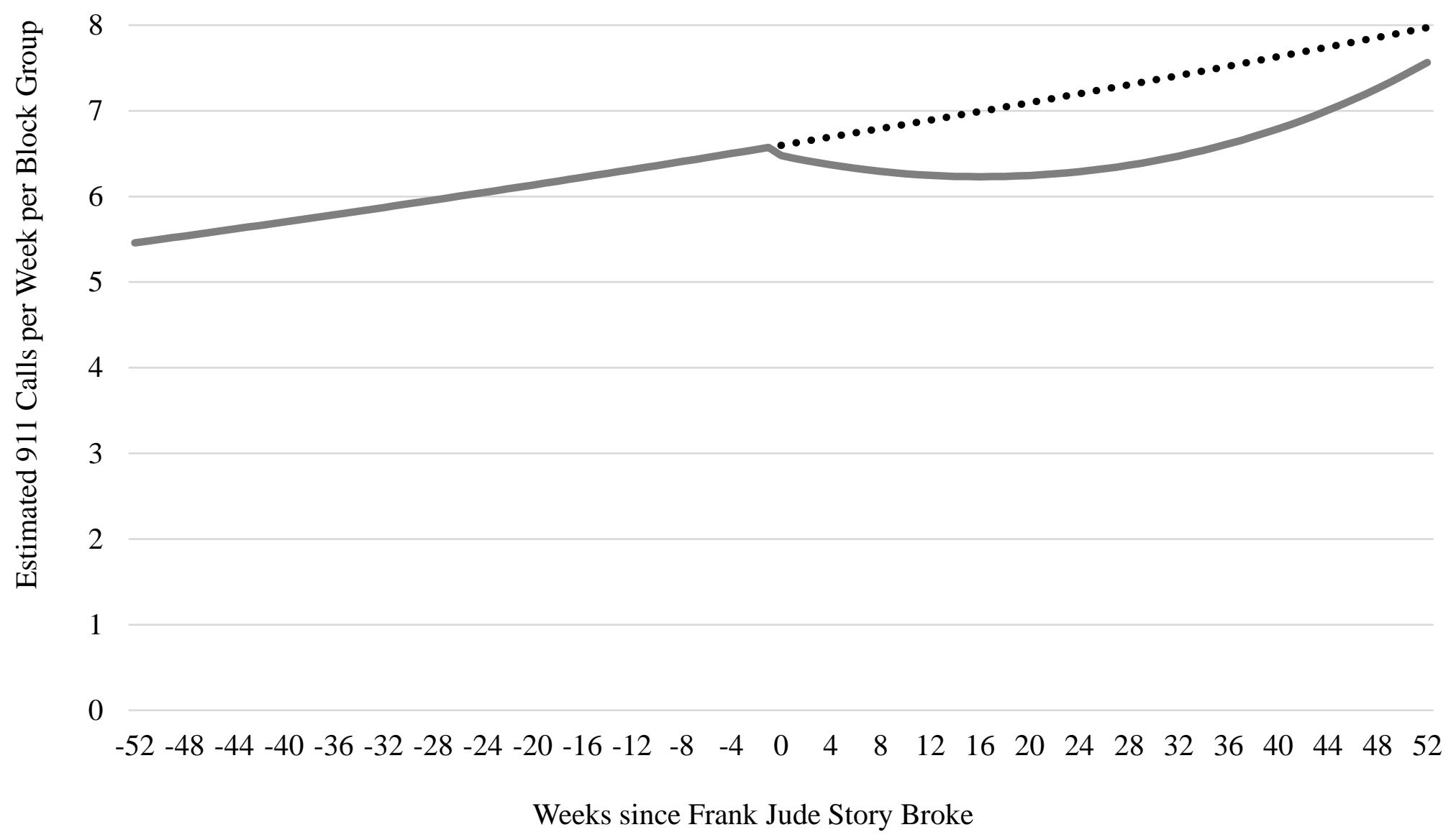

Figure 2. Estimated Number of Weekly 911 Calls Reporting Crime Before and After the Frank Jude Story 


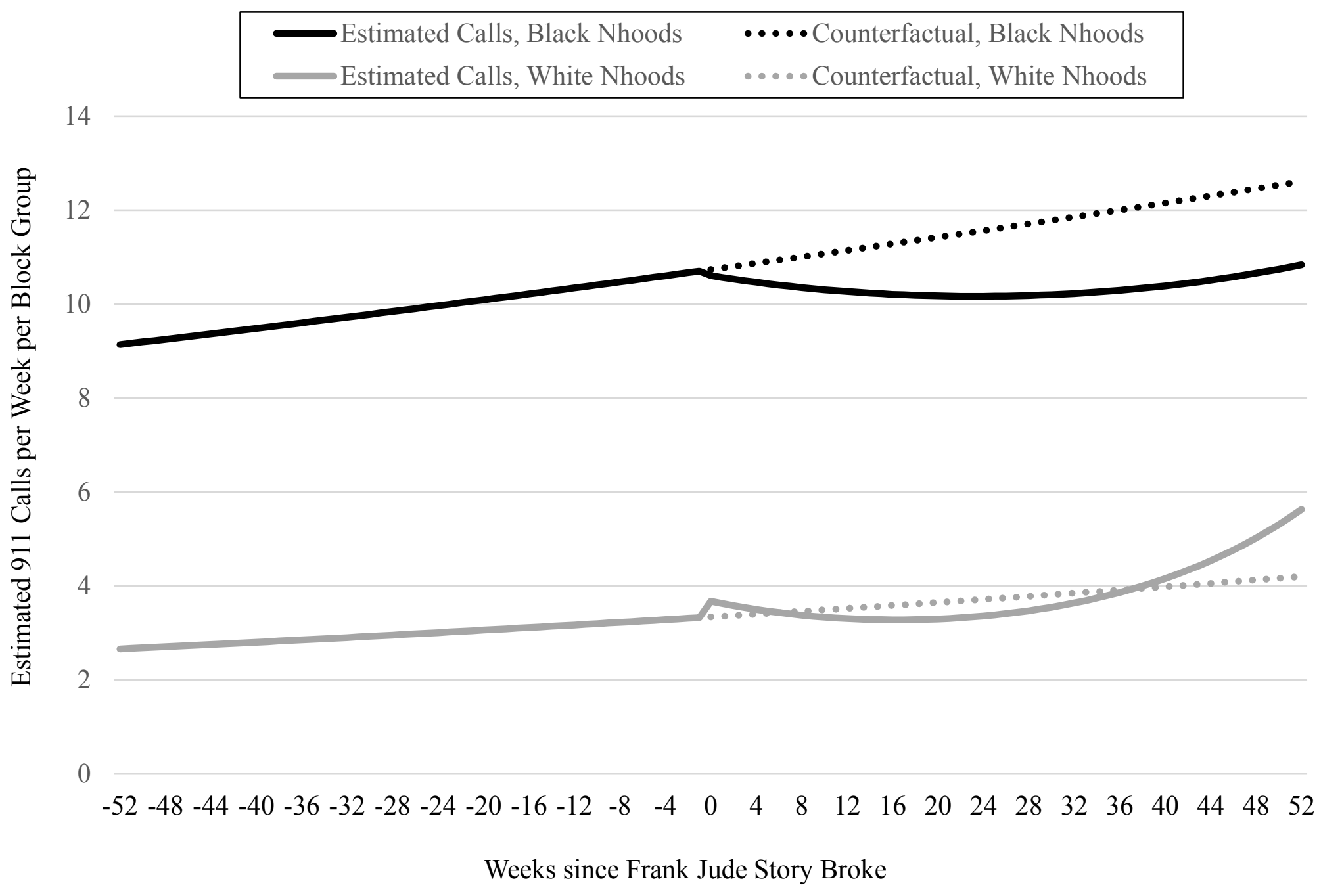

Figure 3. Estimated Number of Weekly 911 Calls Reporting Crime Before and After the Frank Jude Story in White and Black Neighborhoods 


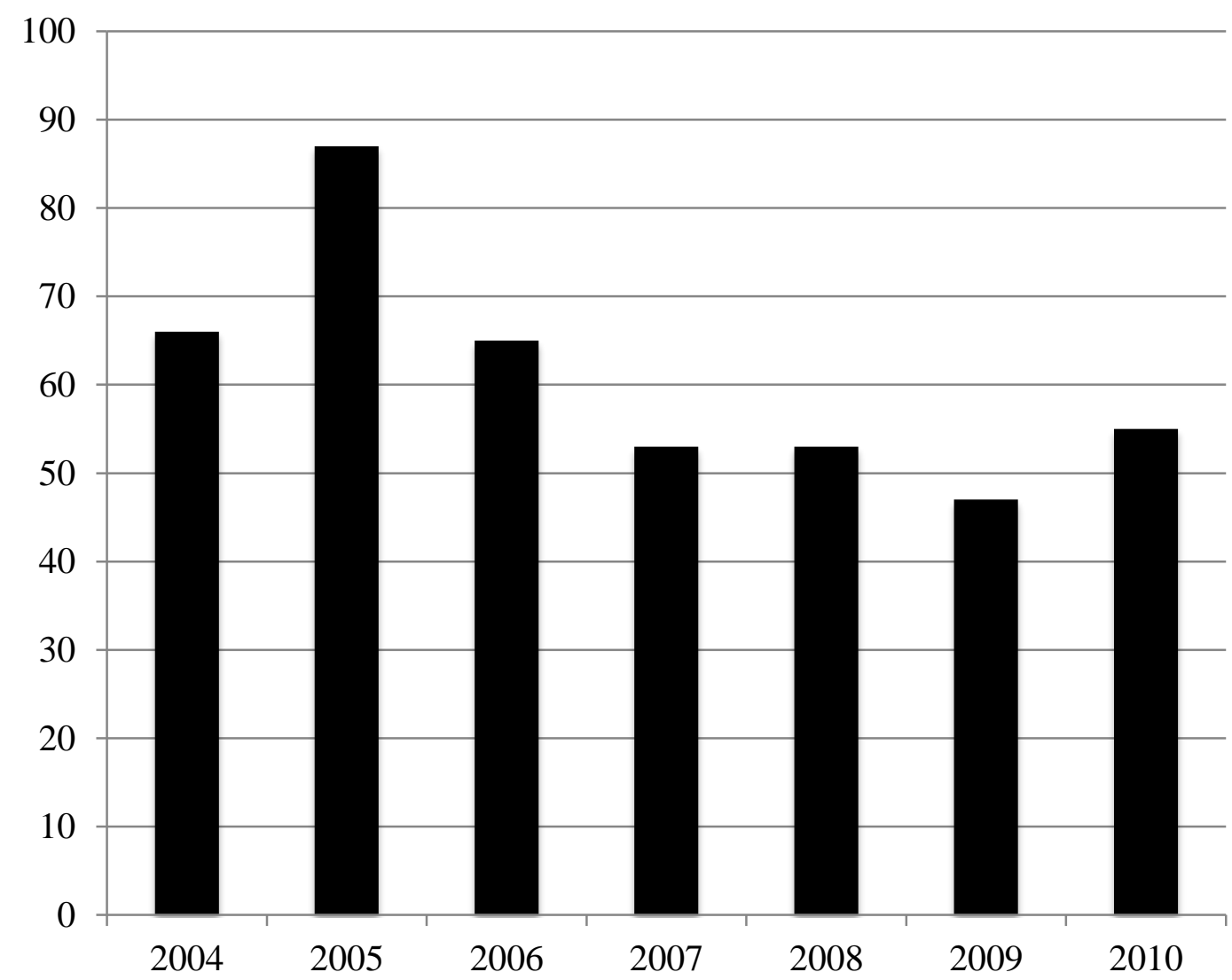

Figure 4. Homicides in Milwaukee, March through August, 2004 to 2010 